\title{
Machine Utilization Rates, Energy Requirements and Greenhouse Gas Emissions of Forest Road Construction and Maintenance in Romanian Mountain Forests
}

\author{
A. Enache and K. Stampfer \\ University of Natural Resources and Life Sciences, Vienna, Austria \\ Corresponding Authors: \{adrian.enache; karl.stampfer\}@boku.ac.at
}

Received 4 July 2014; Accepted 27 November 2014;

Publication 19 March 2015

\begin{abstract}
The FAO and EU forest strategies advocate the use of forest resources in ways which minimize the impact on the environment and climate. However, in forests with poor accessibility, the environmental footprint of forest operations is significant due to the long timber extraction distances. Thus, improving the environmental performance of forest operations requires a well-developed forest infrastructure, specifically the density and quality of roads. The aim of this paper was to assess the environmental footprint of forest roads in terms of embodied energy and greenhouse gas emissions due to construction and maintenance. In this respect, life cycle assessment approach was used to develop an input-output model for benchmarking two case study areas, considering real machine utilization rates, fuel consumption and labor requirements. The forest road life cycle was set to 30 years. Direct energy requirements derived from the fuel consumed by the machinery were considered. Construction and maintenance required energy inputs of $490.9 \mathrm{MJ} \mathrm{m}^{-1}$ and $580.4 \mathrm{MJ} \mathrm{m}^{-1}$, respectively about $36.6 \mathrm{~kg} \mathrm{CO}_{2 \mathrm{eq}} \mathrm{m}^{-1}$ and $43.1 \mathrm{~kg} \mathrm{CO}_{2 \mathrm{eq}} \mathrm{m}^{-1}$ emission rates in the two case study areas, while occupying productive land with forest roads triggered a loss of $3.95 \mathrm{~kg} \mathrm{CO} \mathrm{CO}_{2 \mathrm{eq}}$ $\mathrm{m}^{-1} \mathrm{y}^{-1}$ and $4.40 \mathrm{~kg} \mathrm{CO}_{2 \mathrm{eq}} \mathrm{m}^{-1} \mathrm{y}^{-1}$ during the life cycle of the forest

Journal of Green Engineering, Vol. 4, 325-350.

doi: 10.13052/jge1904-4720.445

(c) 2014 River Publishers. All rights reserved.
\end{abstract}


road. However, the $\mathrm{CO}_{2 \text { eq }}$ loss due to road construction and maintenance is insignificant when compared to the $\mathrm{CO}_{2 \mathrm{eq}}$ stored in the growing stock of the opened forest area. Terrain characteristics showed a strong influence on the amount of fuel consumption, required energy input and GHG emissions, leading to higher environmental burden and higher road construction costs.

Keywords: Emissions, energy efficiency, forest, greenhouse gases, LCA, road construction, Romania.

\section{Introduction}

The EU 20-20-20 targets on climate change and energy sustainability envisage $20 \%$ reduction of greenhouse gas (GHG) emissions from 1990 levels and improving with $20 \%$ the energy efficiency by year 2020 . Forests and their sustainable management play a major role in the reduction of GHG emissions level and in carbon storage in forest biomass (Kilpeläinen et al. 2011). The FAO and EU forest policy framework promote a holistic approach to the challenges of the entire forest value chain for adapting forests to climate change and for reducing the environmental footprint of forest operations within the framework of a low carbon economy. However, in forests with poor accessibility, the environmental footprint of forest operations is significant due to the long timber extraction distances.

Romanian forests cover 6.65 million ha $(29 \%$ of the total land area; Abrudan et al. 2009) and have a poorly developed and unevenly distributed infrastructure (road density $6.5 \mathrm{~m} \mathrm{ha}^{-1}$; Olteanu 2008). Thus, skidding is the main method of timber extraction and the mean skid distance is about $1.8 \mathrm{~km}$ at national level (Popovici et al. 2003). Consequently, the environmental footprint of forest operations is high, while the productivity in timber harvesting and extraction is rather low (Borz et. al 2013; Enache et al. 2013). The average annual growth of Romanian forests is about 37 million $\mathrm{m}^{3}$, the annual allowable cut (AAC) is 22.3 million $\mathrm{m}^{3}$ and the average annual removal is about 17.0 million $\mathrm{m}^{3}$ (World Bank 2012). About $65 \%$ of the forests are located in mountain ranges, $55 \%$ are state-owned forests and $45 \%$ non-state forests. The underdeveloped forest infrastructure makes sustainable forest management challenging, with significant pressure and environmental footprint on the accessible forests. However, the net forest growth in the last decades was positive, ranging between 15-17 million $\mathrm{m}^{3}$ each year, triggering a consequent increase of carbon storage 
(World Bank 2012). This means there is significant potential for increasing the sustainable wood mobilization, which requires a well-developed forest infrastructure.

Timber harvesting and road engineering have the most visible environmental impact in the forest sector. The life cycle assessment (LCA) is a suitable tool for approaching such challenges of the wood supply chain and for producing reliable indicators on the environmental performance of systems and processes in the forest sector (Heinimann 2012). Meister (1995) emphasized that the environmental balance of forest operations is based on mass flows and energy balance of inputs and outputs of a system. In addition, Richter (1995) stressed that defining the boundaries of a LCA system is difficult, highlighting that wood supports most of the negative burdens of the forest management activities, while other ecosystem services of the forest management with direct positive effects on people and the environment do not. The environmental performance of silviculture operations, timber harvesting and transport have been extensively addressed in the literature (Berg and Lindholm 2005; Johnson et al. 2005; Klvac and Skouppy 2009; Michelsen et al. 2008; Seppala et al. 1998; Klvac et al. 2012), while only few studies have included forest roads in the analyzed system boundaries (Berg and Karjalainen 2003; Bosner et al. 2012; Whittaker et al. 2011). American researchers focused more on the effects of forest roads on soil erosion, sedimentation and water quality (Coulter 2004; Mills, 2006; Loeffler et al. 2008), whilst European researchers focused on the embodied energy and GHG emissions of forest roads (Heinimann and Maeda-Inhaba 2003; Heinimann 2012; Whittaker et al. 2011). Since the environmental impact of roads relate to their construction, maintenance and use (Treloar et al. 2004), complete LCA of forest roads is difficult and time consuming, depending on the system boundaries and on the number of inputs in the process analysis. Hence, a hybrid process based and input-output based LCA approach is recommendable for estimating project specific environmental impacts of forest roads (Treloar et. al 2004; Sharrard 2007).

In this context, considering the current concerns on the environmental performance of forest management activities (Abrudan et al. 2009; Karjalainen et al. 2003; Michelsen et al. 2008; Olofsson et al., 2011), the aim of this paper was to quantify the embodied energy, the loss of productive land and the GHG emissions from forest roads construction and maintenance through a comparative assessment of two case study areas. In this respect, a hybrid LCA approach was used, referring to the functional unit of road. 


\section{Material and Methods}

\subsection{Pre-Set Standards}

This study focused on the energy requirements and GHG emissions of forest roads due to construction and maintenance during their life cycle. In this respect, the following standards were established: real utilization rates of machinery and consumption rates of materials and labor; real transport distances for machinery and materials; AAC of the forest area assigned to the forest roads; the life cycle of the forest roads was set to 30 years. The $\mathrm{CO}_{2 \mathrm{eq}}$ emissions were determined for a complete cycle of the diesel combustion process based on a stoichiometric combustion model (Heinimann 2012), for a net calorific value of diesel engines of $42.76 \mathrm{MJ} \mathrm{kg}^{-1}$ (Stanescu 2012) and the diesel density of $0.835 \mathrm{~kg} \mathrm{~m}^{-3}$ (Berg and Karjalainen 2003). The loss of productive land due to road construction was quantified for an average annual growth of $6.0 \mathrm{~m}^{3} \mathrm{ha}^{-1}$. For timber transport, the truck and trailer system with loading capacity of $25 \mathrm{~m}^{3}$ was considered.

\subsection{Input-Output LCA Model and System Borders}

The energy efficiency and the emissions of greenhouse gases are important elements in LCA which focuses on the global warming potential (GWP) of a system. A typical LCA consists of setting goals and objectives, inventory analysis, impact assessment and interpretation of results (Heinmann 2012), while an optimal hybrid LCA model for construction should include economics, on-site activities, equipment, transportation, water, energy and social equity related aspects (Sharrard 2007). The hybrid LCA is based on deriving an input-output (I-O) LCA model and then case-specific LCA data for the analyzed system which are substituted in the I-O model (Treloar et al. 2004).

Heinimann and Maeda-Inaba (2003) showed how the concepts of commodities and activities and the oriented graph theory can be used in investigating I-O flows in forest roads construction. Figure 1 shows the LCA model of forest roads developed in this study for investigating the inputoutput flows of the road construction and maintenance works. This model refers only to the life cycle inventory of the roads and allows identification of material, energy, labor and emission flows within the system. The model was applied for both road construction and maintenance works, referring to activities such as: preparatory works (i.e. transport of machinery and material to the site, road bed clearance); embankments execution, drainage system and pavement finishing; and maintenance works (i.e. pavement reshaping; 


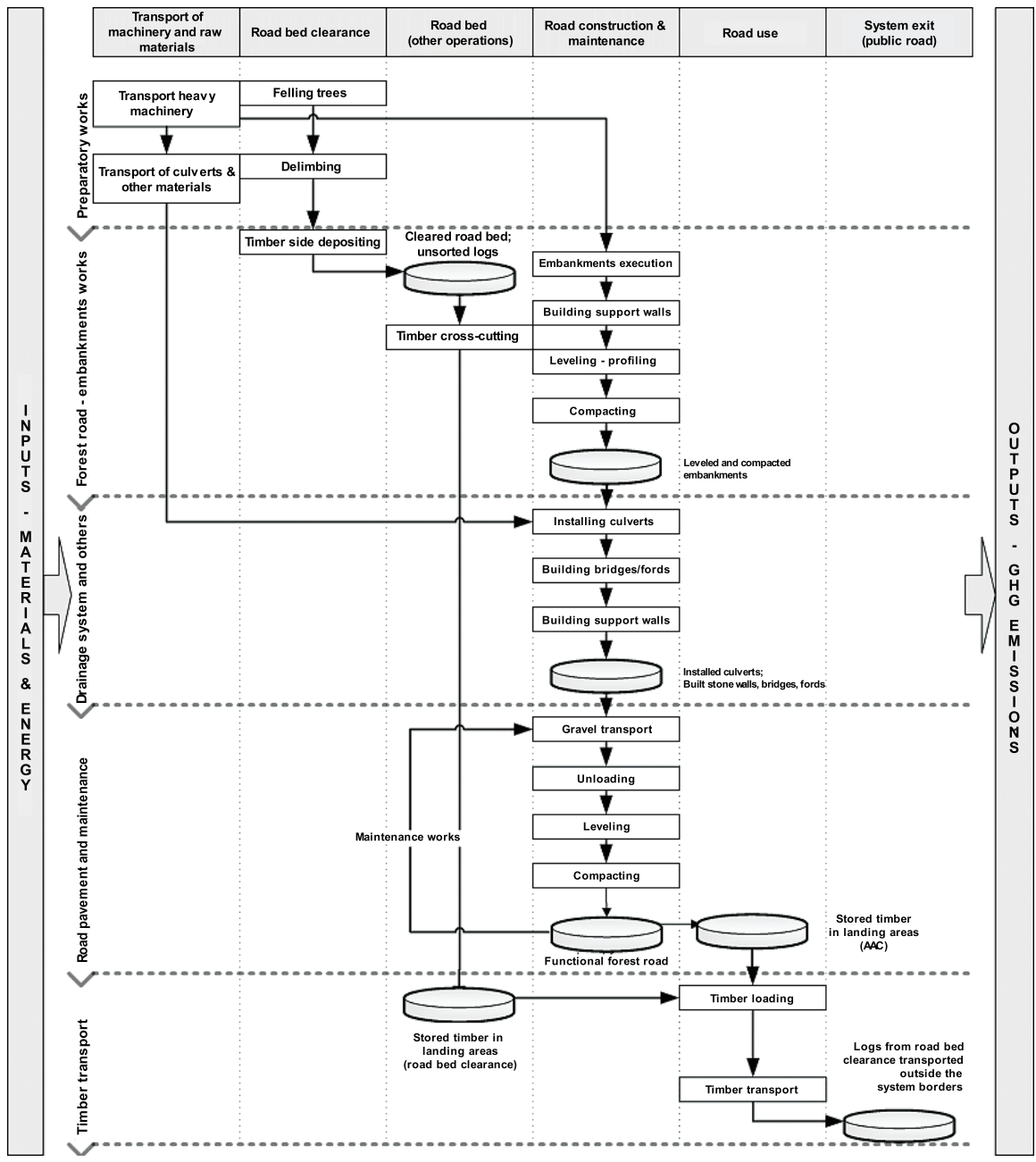

Figure 1 Life cycle I-O model for forest road construction and maintenance.

ditches reshaping). Direct energy requirements and greenhouse gas emissions were derived from the fuel consumed by machinery to carry out specific tasks (Whittaker et al. 2011), disregarding the energy and the emissions embodied in the machinery manufacture. The functional unit of the analyzed system set in this study was one meter of road.

Except for the timber cleared during the road construction, timber harvesting and transport were not included in analysis in this study. Accounting 
of the energy and emissions applied to timber harvesting and extraction with and without forest road will be approached in another study.

\subsection{Building Technology Matrices}

The quantification of the input and output flows for each phase of the LCA (Figure 1) were based on the technology matrices approach, using a system of linear equations which describe the flow of commodities into the system (Michelsen et al. 2008; Heinimann 2012), an example of which is presented in Table 1 for the phase of pavement works. The first row of the matrix shows the flow of labor necessary for a given process, taking into account the effective working time of a machine operator. The second row shows the fuel consumption rates of the machineries per productive system hour (PSH), which means the system includes both the machinery and the operator. The following rows were filled using the same reasoning. Thus, if a machine was not used in the system, all values in the row assigned to that machine were set to zero, except the diagonal value which was always set to value 1 .

According to Heinimann (2012), assuming that each process can be scaled by a variable $\mathrm{x}_{i(i=1 \div n)}$, the system of equations can be solved for the vector $X\left(x_{1}, x_{2}, \ldots, x_{n}\right)$ if the total production of the system is known, that is vector $\mathrm{Y}$, using the equations bellow.

$$
\begin{array}{ll}
\text { Equation (1) } & A \cdot X=Y \\
\text { Equation (2) } & X=A^{-1} \cdot Y
\end{array}
$$

The economic performance of the systems was determined using a cost vector based on the machine hour costs computed with the FAO cost calculation scheme (Holzleitner, 2011), which was then multiplied with the performance vector $\mathrm{X}$. Considering the direct correlation between the flow of commodities and their environmental footprint (Heinimann 2012), an environmental matrix similar to the technology matrix from the Table 1 was developed. This matrix was then multiplied with the performance vector $\mathrm{X}$, and the environmental footprint vector of the analyzed system was thus determined. The technology matrix approach was used in benchmarking both forest road construction and maintenance works.

\subsection{Case Study Areas (CSAs)}

The research was conducted in Lignum Forest Enterprise, located in Bacau County (Romania), Eastern Carpathian Mountains ( $46^{\circ} 21^{\prime} 02^{\prime \prime N}, 26^{\circ} 20^{\prime} 42^{\prime \prime E}$; Figure 2), in the surroundings of Accumulation Lake "Valea Uzului" 
Machine Utilization Rates, Energy Requirements and Greenhouse Gas Emissions 331

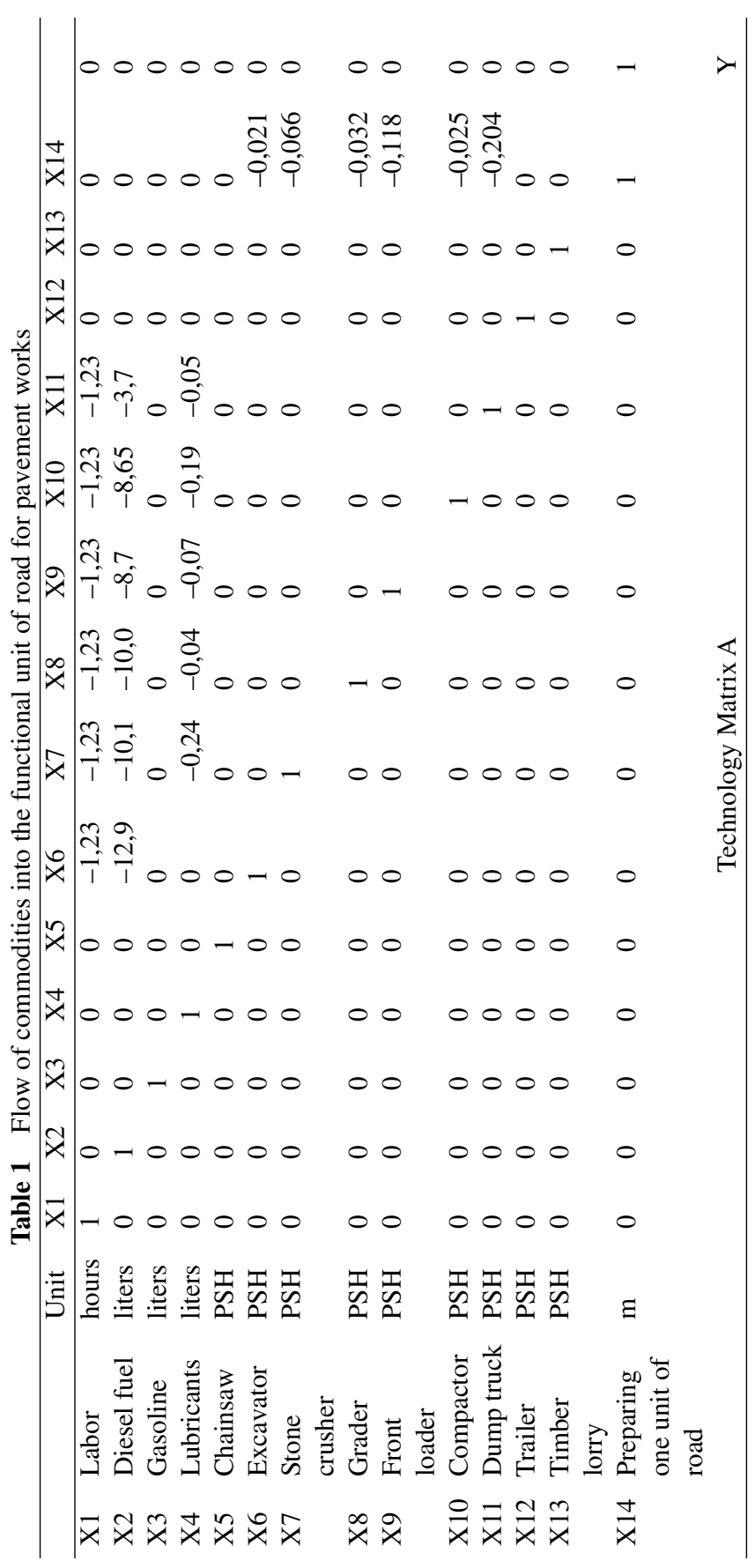




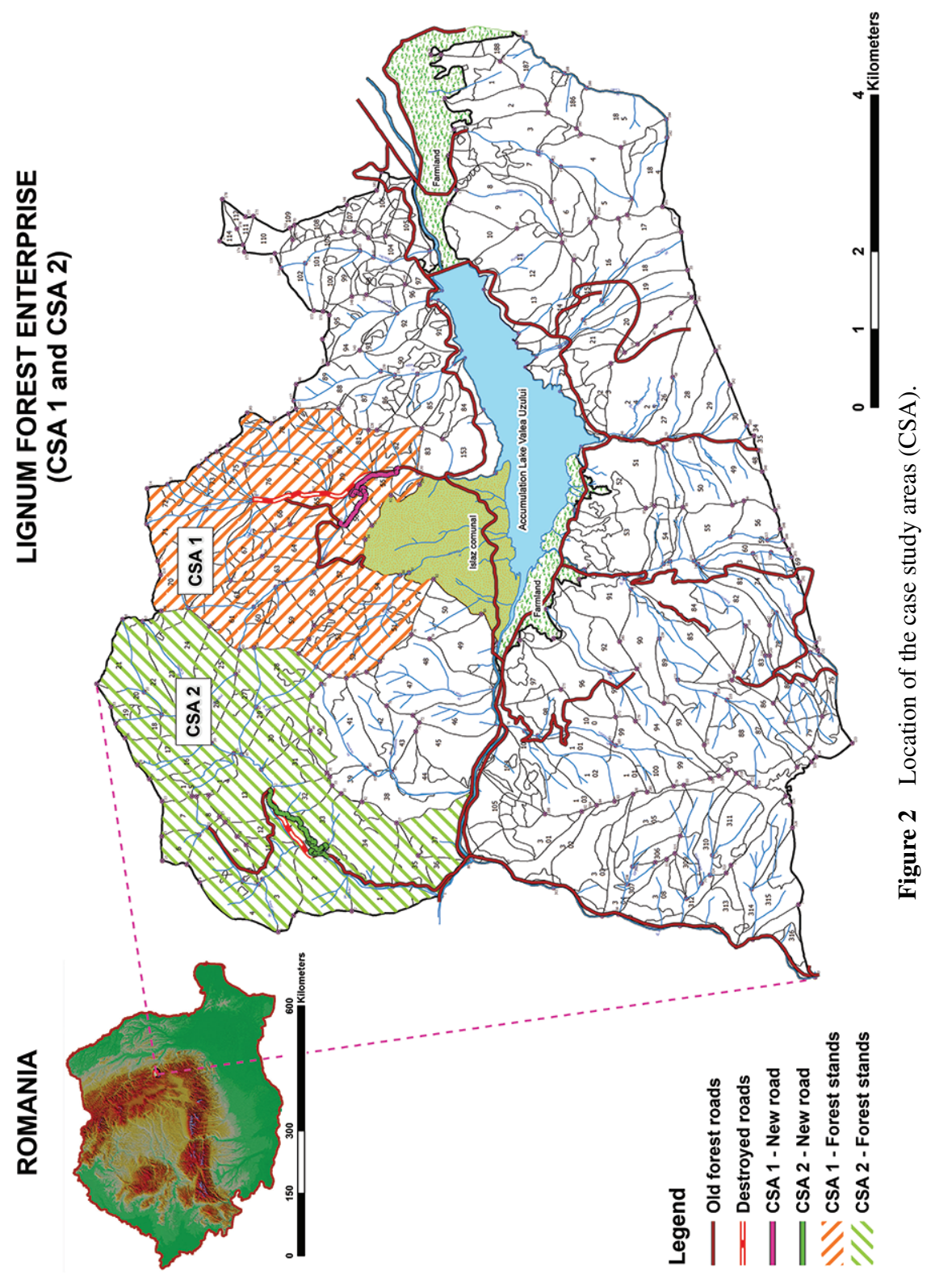


which provides drinking water for 27 communities with about 370000 inhabitants.

The forest enterprise manages about 6500 ha of mixed broadleavesconiferous forests, of which $85 \%$ have mainly protective functions for water quality. The rotation of forest stands is about 100-110 years for conifers and 110-120 years for broadleaves. The bedrock is of Paleocene age, mainly sandstones, marl schist and alluvial formations, while the most common soil types are brown forest soils (75\% of the area) and acid brown soils (25\%). The density of forest roads is about $7.6 \mathrm{~m} \mathrm{ha}^{-1}$, with roads located mostly along the valleys. Timber extraction is done by tractors and skidders (65\% of AAC), forwarders $(21 \%)$, horse harnesses $(8 \%)$ and cable yarders $(6 \%)$. Two case study areas were selected for analysis: CSA 1 - Forest Road Plopu-Lapos and CSA 2 - Forest Road Coporaia (Table 2).

For each CSA, data of the following machineries used in road construction was collected from the records of the forest enterprise: chainsaw, excavator, stone crusher, grader, front loader, compactor, dump truck, trailer and timber lorry (Table 3). For road maintenance, data was gathered from the records of the maintenance works conducted in 2013 across the entire forest district for old valley forest roads, for the following machinery: backhoe loader, stone crusher, grader, compactor, dump truck and trailer.

\subsubsection{CSA 1 - Forest Road "Plopu-Lapos"}

The Plopu-Lapos forest road was built in 2013 and serves about 842 ha of forests (Figure 2), with an AAC of about $4000 \mathrm{~m}^{3} \mathrm{y}^{-1}$. The road has a length of $1.7 \mathrm{~km}$, an average road bed width of $3.5 \mathrm{~m}$ and cross stations with an average width of about $7.0 \mathrm{~m}$ and $20 \mathrm{~m}$ length, located at intervals of 300 to $400 \mathrm{~m}$. The permanent surface occupied by the road is about $1.02 \mathrm{ha}$, and the pavement structure is of $0.40 \mathrm{~m}$ thickness with gravel from on-site provenience. The road was built in moderate terrain conditions, using

Table 2 Key facts about case study areas

\begin{tabular}{lll}
\hline Item & CSA 1 & CSA 2 \\
\hline Length of the new forest road (m) & 1707 & 1968 \\
Forest area served by the road (ha) & 841.8 & 704.0 \\
Current standing volume $\left(\mathrm{m}^{3}\right)$ & 287754 & 252042 \\
Estimated increment in 30 years $\left(\mathrm{m}^{3}\right)$ & 151376 & 142032 \\
Estimated gross standing volume after 30 years $\left(\mathrm{m}^{3}\right)$ & 439130 & 394074 \\
Estimated harvests in 30 years $\left(\mathrm{m}^{3}\right)$ & 120000 & 113600 \\
Estimated net standing volume in 30 years $\left(\mathrm{m}^{3}\right)$ & 319130 & 280474 \\
\hline
\end{tabular}




\section{A. Enache and K. Stampfer}

Table 3 Key facts of the machinery used in road construction and maintenance

\begin{tabular}{lllll}
\hline & & Weight & $\begin{array}{l}\text { Engine } \\
\text { Power }\end{array}$ & $\begin{array}{l}\text { Production } \\
\text { year }\end{array}$ \\
\hline Excavator & Producer/Model & 22,5 to & $110 \mathrm{kw}$ & 2006 \\
Stone crusher & Hartl MT 503 BBV & 31,8 to & $186 \mathrm{kw}$ & 1999 \\
Grader & O\&K F156A & 15,8 to & $112 \mathrm{kw}$ & 2001 \\
Compactor & Caterpillar CS583 C & 14,7 to & $72 \mathrm{kw}$ & 2000 \\
Bulldozer & Liebherr LR 632 & 20 to & $89 \mathrm{kw}$ & 1998 \\
Front loader & Liebherr LR 632 & 22 to & $132 \mathrm{kw}$ & 2004 \\
Dump truck & MAN TG 3348 & 33 to/14 to & $353 \mathrm{kw}$ & 2008 \\
Timber lorry & Mercedes-Benz Actros 3348 & 33 to/16 to & $350 \mathrm{kw}$ & 2007 \\
Trailer & EMPL TLU 4X11 & 24 to & N/A & 1998 \\
Chainsaw & Husqvarna 372 XP & $6,1 \mathrm{~kg}$ & $3,9 \mathrm{kw}$ & 2012 \\
Backhoe loader & Terex TX760B & 6,8 to & $69 \mathrm{kw}$ & 2005 \\
\hline
\end{tabular}

a mixed cut-fill profile, with approximately $35 \%$ of the road length on low slope terrain and $65 \%$ of it on moderate slopes (Table 4). About $99 \%$ of the embankment works represented earth mass movements, while only $1 \%$ was rock mass movement, with no additional necessary works for stabilizing the slopes (Table 5). Before the new road was built no timber harvesting was

Table 4 Classification of forest roads by slope classes of the terrain in each CSA

\begin{tabular}{lccccc}
\hline & \multicolumn{2}{c}{ Road CSA1 } & & \multicolumn{2}{c}{ Road CSA2 } \\
\cline { 2 - 3 } \cline { 5 - 6 } Forest roads & Length $(\mathrm{m})$ & Share $(\%)$ & & Length $(\mathrm{m})$ & Share $(\%)$ \\
\hline Side slope classes & & & & \\
of the terrain & 600,0 & $35 \%$ & & 500,0 & $25 \%$ \\
$\quad<25 \%$ & 1107,0 & $65 \%$ & & 510,0 & $26 \%$ \\
$25-40 \%$ & 0,0 & $0 \%$ & & 775,0 & $39 \%$ \\
$40-55 \%$ & 0,0 & $0 \%$ & & 183,0 & $9 \%$ \\
$>55 \%$ & 1707,0 & $100 \%$ & 1968,0 & $100 \%$ \\
\hline Total road length $(\mathrm{m})$ & & & & \\
\hline
\end{tabular}

Table 5 Characteristic of embankment works in each CSA

\begin{tabular}{lccccc}
\hline & \multicolumn{2}{c}{ Road CSA1 } & & \multicolumn{2}{c}{ Road CSA2 } \\
\cline { 2 - 3 } \cline { 5 - 6 } Forest roads & Volume $\left(\mathrm{m}^{3}\right)$ & Share $(\%)$ & & Volume $\left(\mathrm{m}^{3}\right)$ & Share $(\%)$ \\
\hline Total embankment & 8179 & $100 \%$ & & 24097 & $100 \%$ \\
works $\left(\mathrm{m}^{3}\right)$ & & & & 9880 & $41 \%$ \\
- earth mass movement & 8104 & $99 \%$ & & 14217 & $59 \%$ \\
- rock mass movement & 75 & $1 \%$ & & & \\
\hline Stabilizing support & 0 & - & & 454 & - \\
walls $\left(\mathrm{m}^{3}\right)$ & & & &
\end{tabular}


possible due to lack of access, currently the timber extraction is entirely done by skidders and forwarders.

\subsubsection{CSA 2 - Forest Road "Coporaia"}

The Coporaia forest road was built in 2011 and serves about 704 ha of forests (Figure 2), with an AAC of about $5250 \mathrm{~m}^{3} \mathrm{y}^{-1}$. The new road has a length of $2.0 \mathrm{~km}$, an average road bed width of $3.5 \mathrm{~m}$, cross station widths of about $7.0 \mathrm{~m}$ and $0.70 \mathrm{~m}$ thick gravel pavement from on-site provenience. The permanent surface occupied by this road is about 1.31 ha. The road was built in difficult terrain conditions; about $48 \%$ of the road length is located in steep and very steep terrain while $26 \%$ of the road length is on moderate slopes (Table 4). For steep and very steep slopes the road was built mostly in full bench profile, while for moderate slopes the mixed cut-fill profile was used. About $41 \%$ of the embankment works represented earth mass movements, while 59\% was rock mass movement and about $450 \mathrm{~m}^{3}$ of stones were necessary for stabilizing the slopes with supporting walls (Table 5). Before the road was built, timber extraction was done entirely with skidders on distances up to $3.5 \mathrm{~km}$, while currently used extraction technologies are the skidders and forwarders $(65 \%$ of the harvested volume) and the cable yarders (35\%).

\subsubsection{Road Maintenance}

According to the Romanian regulations, the road maintenance works should be carried out regularly depending on the category of the forest road and of the amount of timber transported on it. Thus, considering the road network consists mainly of valley forest roads, Lignum Forest Enterprise performs road maintenance works at intervals of two years for each forest road. The maintenance works were split in two categories: one referring to pavement works (i.e. road bed and pavement structure reshaping, gravel replacement whenever necessary, leveling and compacting) and another one referring to the drainage system works (i.e. reshaping and cleaning the side ditches and the culverts). The collected data refers to maintenance works performed in 2013 on old valley forest roads which serve a total forest area of 750 ha with an AAC of $7500 \mathrm{~m}^{3} \mathrm{y}^{-1}$ (35\% thinning, 50\% final cuts and 15\% sanitary cuts). The total length of repaired ditches was $7000 \mathrm{~m}$ and the total length of reshaped road bed pavement was about $2500 \mathrm{~m}$. An additional amount of 85 $\mathrm{m}^{3}$ of gravel was required for reshaping the pavement structure of the road. The gravel was transported from a local gravel deposit located $17 \mathrm{~km}$ away from the site. 


\section{Results}

\subsection{Machine Utilization Rates}

\subsubsection{Road Construction}

The fuel consumption rates and the machine utilization rates for each phase of the road construction in CSA 1 are depicted in Table 6. For building one meter of road in CSA 1, 0.930 man-hours, 6.19 liters of diesel and 0.772 machine-hours were required. Out of the latter ones about $28 \%$ were excavator hours, $27 \%$ were dump truck hours and $15 \%$ were front loader hours.

The most intensive phases of road construction (in terms of labor, fuel consumption and machine utilization) were the embankments execution and the pavement works. The execution of embankments required about $26 \%$ of the labor, $39 \%$ of the fuel and $25 \%$ of the machinery utilization from the total amounts needed for building the road. For the pavement works, about $62 \%$ of the labor, $52 \%$ of the fuel and $60 \%$ of the machinery utilization were required.

The fuel consumption rates and the machine utilization rates for each phase of the road construction in CSA 2 are depicted in Table 7. For building one meter of road in CSA 2 were necessary about 8.59 liters of diesel and 1.084 machine-hours, out of which $31 \%$ were excavator hours, $23 \%$ were dump truck hours and $15 \%$ were front loader hours. Similar to CSA 1, the most intensive phases of the road construction in terms of labor requirements,

Table 6 Utilization rates of fuel, labor and machinery in CSA 1

\begin{tabular}{|c|c|c|c|c|c|c|}
\hline Commodities & & $\begin{array}{l}\text { Preparatory } \\
\text { Works }\end{array}$ & $\begin{array}{l}\text { Embankment } \\
\text { Works }\end{array}$ & $\begin{array}{l}\text { Drainage } \\
\text { system }\end{array}$ & $\begin{array}{l}\text { Pavement } \\
\text { works }\end{array}$ & $\begin{array}{l}\text { Total Road } \\
\text { Construction }\end{array}$ \\
\hline Labor & hours & 0.086 & 0.239 & 0.032 & 0.573 & 0.930 hours \\
\hline Diesel fuel & liter & 0.192 & 2.420 & 0.336 & 3.242 & 6.191 liter \\
\hline Gasoline & liter & 0.058 & 0 & 0 & 0 & 0.058 liter \\
\hline Lubricants & liter & 0.031 & 0.035 & 0 & 0.039 & 0.105 liter \\
\hline Chainsaw & PSH & 0.042 & 0 & 0 & 0 & $0.042 \mathrm{PSH}$ \\
\hline Excavator & PSH & 0 & 0.170 & 0.026 & 0 & $0.217 \mathrm{PSH}$ \\
\hline $\begin{array}{l}\text { Stone } \\
\text { crusher }\end{array}$ & PSH & 0 & 0 & 0 & 0.066 & $0.066 \mathrm{PSH}$ \\
\hline Grader & PSH & 0 & 0.016 & 0 & 0.032 & $0.047 \mathrm{PSH}$ \\
\hline Front loader & PSH & 0 & 0 & 0 & 0.118 & $0.118 \mathrm{PSH}$ \\
\hline Compactor & PSH & 0 & 0.008 & 0 & 0.025 & $0.033 \mathrm{PSH}$ \\
\hline Dump truck & PSH & 0.004 & 0 & & 0.204 & $0.208 \mathrm{PSH}$ \\
\hline Trailer & PSH & 0.014 & 0 & 0 & 0 & $0.014 \mathrm{PSH}$ \\
\hline $\begin{array}{l}\text { Timber } \\
\text { lorry }\end{array}$ & PSH & 0.026 & 0 & 0 & 0 & $0.026 \mathrm{PSH}$ \\
\hline Road unit & $\mathrm{m}$ & 1 & 1 & 1 & 1 & $\mathrm{~m}$ \\
\hline
\end{tabular}


Table 7 Utilization rates of fuel, labor and machinery in CSA 2

\begin{tabular}{llllllll}
\hline & & Preparatory Embankment & Drainage & \multicolumn{2}{l}{ Pavement Total Road } \\
Commodities & & Works & Works & system & works & \multicolumn{2}{l}{ Construction } \\
\hline Labor & hours & 0.187 & 0.462 & 0.024 & 0.411 & 1.084 & hours \\
Diesel fuel & liter & 0.375 & 5.080 & 0.313 & 2.818 & 8.586 & liter \\
Gasoline & liter & 0.170 & 0 & 0 & 0 & 0.170 & liter \\
Lubricants & liter & 0.090 & 0.058 & 0 & 0.042 & 0.190 & liter \\
Chainsaw & PSH & 0.123 & 0 & 0 & 0 & 0.123 & PSH \\
Excavator & PSH & 0 & 0.308 & 0.024 & 0 & 0.337 & PSH \\
Stone & PSH & 0 & 0 & 0 & 0.075 & 0.075 & PSH \\
crusher & & & & & & & \\
Grader & PSH & 0 & 0.022 & 0 & 0.004 & 0.025 & PSH \\
Front loader & PSH & 0 & 0 & 0 & 0.106 & 0.158 & PSH \\
Compactor & PSH & 0 & 0.014 & 0 & 0.048 & 0.062 & PSH \\
Dump truck & PSH & 0.006 & 0 & 0 & 0.173 & 0.245 & PSH \\
Trailer & PSH & 0.018 & 0 & 0 & 0 & 0.018 & PSH \\
Timber & PSH & 0.040 & 0 & 0 & 0 & 0.040 & PSH \\
lorry & & & & & & & \\
\hline Road unit & $\mathrm{m}$ & 1 & 1 & 1 & 1 & 1 & $\mathrm{~m}$ \\
\hline
\end{tabular}

fuel consumption and machinery utilization in CSA 2 were the embankments execution and the pavement works. The execution of embankments required $43 \%$ of the labor, $59 \%$ of the fuel and $43 \%$ of the machine-hours from the total amounts needed for building the road, while the execution of pavement finishing required $38 \%$ of the labor, $33 \%$ of the fuel and $38 \%$ of the machinery utilization.

\subsubsection{Road Maintenance}

The utilization rates of the machinery used in one road maintenance operation are depicted in Table 8. About 0.5 liter of fuel and 0.072 machine-hours were required for maintaining one meter of road. Hence, during the entire life cycle of the forest road, maintenance works for one meter of road would require about 7.5 liters of fuel and 1.073 machine-hours utilization. The maintenance works of the drainage systems (i.e. reshaping the side ditches and cleaning the culverts) consumed about $60 \%$ of the total labor and fuel required for the road maintenance.

\subsection{Cost Appraisal}

Table 9 shows the structure of the road construction and maintenance effort by type of costs. The total road construction costs were $88.2 € \mathrm{~m}^{-1}$ in CSA 1 , respectively $119.6 € \mathrm{~m}^{-1}$ in CSA 2 . The costs reported for road 
Table 8 Machinery utilization rates for one process of road maintenance

\begin{tabular}{lcccc}
\hline Commodities & Pavement works & Drainage system & \multicolumn{2}{c}{ Total Road Maintenance } \\
\hline Labor & 0.029 & 0.043 & 0.072 & hours \\
Diesel fuel & 0.192 & 0.308 & 0.500 & liter \\
Stone crusher & 0.002 & 0.000 & 0.002 & PSH \\
Grader & 0.006 & 0.000 & 0.006 & PSH \\
Backhoe loader & 0.000 & 0.043 & 0.043 & PSH \\
Compactor & 0.003 & 0.000 & 0.003 & PSH \\
Dump truck & 0.016 & 0.000 & 0.016 & PSH \\
Trailer & 0.002 & 0.000 & 0.002 & PSH \\
\hline Road unit & 1 & 1 & 1 & $\mathrm{~m}$ \\
\hline
\end{tabular}

Table 9 Structure of the road construction and maintenance costs

\begin{tabular}{|c|c|c|c|c|c|c|}
\hline \multirow[b]{2}{*}{ Cost types } & \multicolumn{2}{|c|}{$\begin{array}{l}\text { Road construction } \\
\text { CSA } 1\end{array}$} & \multicolumn{2}{|c|}{$\begin{array}{l}\text { Road construction } \\
\text { CSA } 2\end{array}$} & \multicolumn{2}{|c|}{ Road maintenance } \\
\hline & $€ / \mathrm{m}$ & $\%$ & $€ / \mathrm{m}$ & $\%$ & $€ / \mathrm{m}$ & $\%$ \\
\hline Machinery & 22.0 & 25 & 37.7 & 32 & 1.5 & 51 \\
\hline Fuel & 7.0 & 8 & 10.0 & 8 & 0.7 & 24 \\
\hline Labor & 48.7 & 55 & 67.5 & 56 & 0.7 & 25 \\
\hline Materials & 10.5 & 12 & 4.4 & 4 & 0 & 0 \\
\hline Total costs $(€ / \mathrm{m})$ & 88.2 & 100 & 119.6 & 100 & 2.9 & 100 \\
\hline
\end{tabular}

maintenance, respectively $2.91 € \mathrm{~m}^{-1}$, are those required for performing one operation. Regarding the road construction, in both CSAs, the labor was the most intensive cost factor, representing about 55\% (CSA 1) and 56\% (CSA 2) of the total costs, respectively. The second most important cost factor in road construction was the utilization of machineries, with a share of $25 \%$ in CSA 1 and $32 \%$ in CSA 2 from the total costs. The most important cost factor in road maintenance was the machinery with about $51 \%$ of the total maintenance costs, while labor and fuel consumption had similar shares from the total costs, respectively $24 \%$ and $25 \%$.

Figure 3 reveals the costs with preparatory works, drainage system execution and pavement works were similar in both CSAs, while the execution of embankments was significantly more costly in CSA 2 than in CSA 1, due to the steeper terrain and hence higher amounts of earth and rock excavations. In respect of road maintenance costs during the life cycle of the road, $60 \%$ of the costs are necessary for maintaining the pavement structure of the road and $40 \%$ of the costs for maintaining the drainage system. Considering one maintenance operation is carried out in average once at each two years, this means the yearly road maintenance costs are about $1.45 € \mathrm{~m}^{-1}$. In addition, taking into account an yearly interest rate of $3.5 \%$, the total maintenance costs 


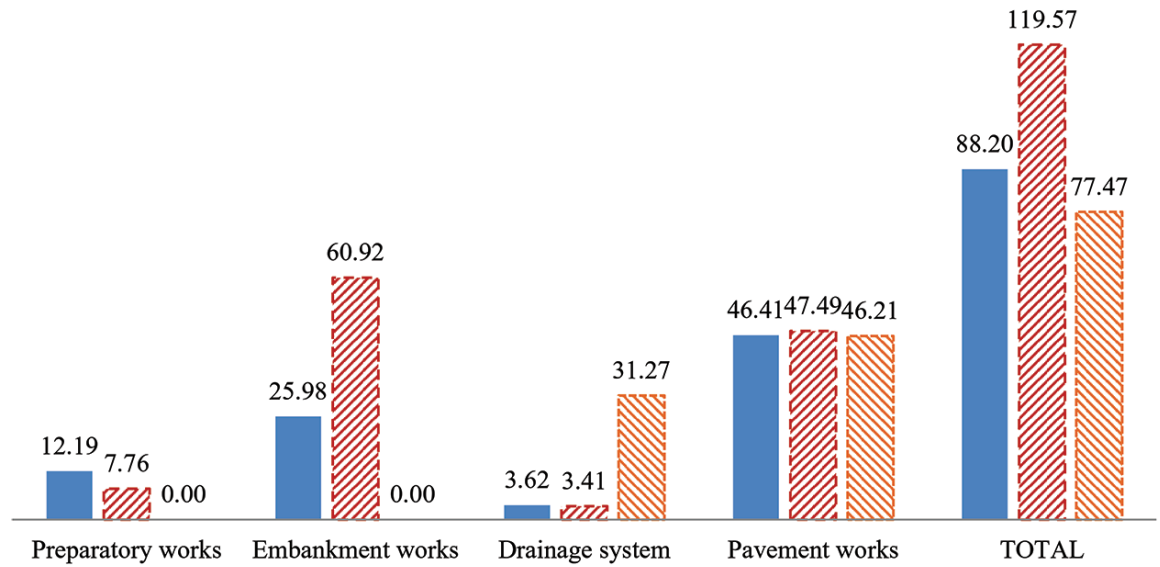

Figure 3 Forest road costs by category of works.

during the life cycle of the forest roads would be $77.5 € \mathrm{~m}^{-1}$ (Figure 3). This means that in moderate terrain conditions (i.e. CSA 1 - slopes below 40\%) the initial investment costs in road construction would be almost equaled by the maintenance costs (about $88 \%$ of the construction costs) during the life cycle of the road, whereas in difficult terrain conditions (i.e. CSA 2 - slopes above $40 \%$ and stony material), the maintenance costs of the road would represent about $66 \%$ of the initial construction costs.

Table 10 presents the utilization rates, the fuel consumption rates and the system hour costs of the machinery (including fuel and labor costs). Slight variations of the machinery system hour costs were noticed between CSA 1 and CSA 2, respectively between road construction and road maintenance. This was probably because of the effective utilization time of the machineries and due to different operators running specific machineries. It has to be noted the forest enterprise used both local labor and Austrian labor for operating the machinery, the latter case being much more expensive, but however with more experience than local operators.

\subsection{Embodied Energy, GHG Emissions and Loss of Productive Land}

The most energy intensive phases in road construction are the embankment and the pavement works in both CSAs (Figure 4). 
Table 10 Total utilization rates, fuel consumption and costs of machinery

\begin{tabular}{|c|c|c|c|c|c|c|c|c|c|}
\hline \multirow{3}{*}{ Machinery } & \multicolumn{6}{|c|}{ Road construction } & \multirow{2}{*}{\multicolumn{3}{|c|}{ Road maintenance }} \\
\hline & \multicolumn{3}{|c|}{ CSA 1} & \multicolumn{3}{|c|}{ CSA 2} & & & \\
\hline & Hours & $\begin{array}{l}\text { Fuel } \\
(1 / h)\end{array}$ & $\begin{array}{l}\text { Costs } \\
(€ / h)\end{array}$ & Hours & $\begin{array}{l}\text { Fuel } \\
(1 / \mathrm{h})\end{array}$ & $\begin{array}{l}\text { Costs } \\
(€ / h)\end{array}$ & Hours & $\begin{array}{l}\text { Fuel } \\
(1 / h)\end{array}$ & $\begin{array}{l}\text { Costs } \\
(€ / \mathrm{h})\end{array}$ \\
\hline Excavator & 370 & 12.9 & 138.1 & 664 & 13.1 & 142.0 & - & - & - \\
\hline Stone crusher & 112 & 10.1 & 134.1 & 112 & 10.1 & 137.8 & 6 & 9.7 & 134.8 \\
\hline Grader & 81 & 9.7 & 96.5 & 50 & 10.0 & 100.5 & 14 & 10.1 & 95.4 \\
\hline Compactor & 57 & 9.1 & 142.7 & 122 & 8.4 & 144.9 & 7 & 8.7 & 112.8 \\
\hline Front loader & 202 & 8.7 & 90.8 & 311 & 8.7 & 101.6 & - & - & - \\
\hline Backhoe loader & - & - & - & - & - & - & 299 & 7.2 & 27.5 \\
\hline Dump truck & 349 & 3.7 & 84.1 & 471 & 3.7 & 108.7 & 40 & 4.6 & 30.7 \\
\hline Timber lorry & 51 & 5.4 & 30.3 & 79 & 5.0 & 21.6 & - & - & - \\
\hline Trailer & 24 & 3.5 & 32.4 & 47 & 7.3 & 57.9 & 5 & 7.3 & 35.1 \\
\hline Chainsaw & 72 & 1.4 & 7.7 & 242 & 1.4 & 8.8 & - & - & - \\
\hline Total & 1318 & - & - & 2133 & - & - & 371 & - & - \\
\hline
\end{tabular}

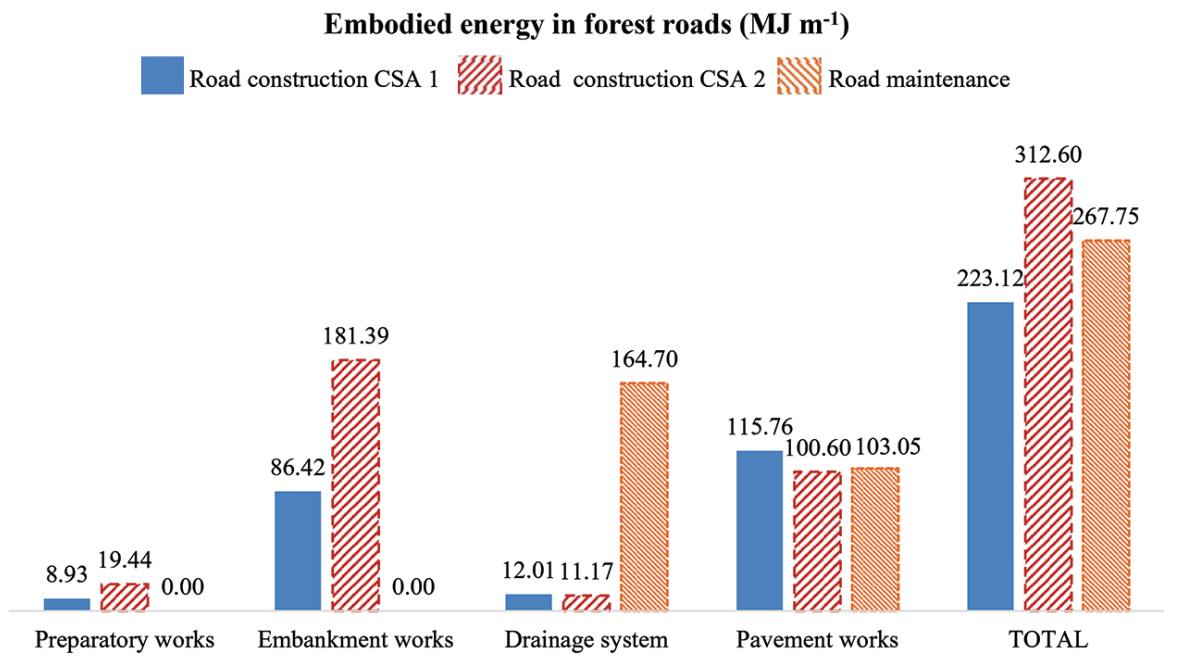

Figure 4 Energy requirements of road construction and maintenance.

Figure 4 reveals a significantly higher energy demand for the embankments execution in CSA $2\left(181.4 \mathrm{MJ} \mathrm{m}^{-1}\right)$ compared to CSA 1 (86.4 $\mathrm{MJ} \mathrm{m}^{-1}$ ). This was due to the steeper terrain and more rock excavations in CSA 2 than in CSA 1 (Table 4 and Table 5), which required more machinery utilization. The total amount of energy required for road construction was 223.12 $\mathrm{MJ} \mathrm{m}^{-1}$ in CSA 1 and $312.60 \mathrm{MJ} \mathrm{m}^{-1}$ in CSA 2 (Figure 4). The 
execution of pavement finishing was the most energy intensive phase in CSA 1 , accounting for about $52 \%$ of the total energy input, while the most energy intensive phase in CSA 2 was the embankment execution, which accounted for about $58 \%$ of the total energy input.

One complete process of road maintenance required about $10.98 \mathrm{MJ} \mathrm{m}^{-1}$ for the construction of the drainage system and about $6.87 \mathrm{MJ} \mathrm{m}^{-1}$ for the pavement works. Although these figures might seem less energy intensive than the road construction, due to the repetition of this process at regular intervals during the entire life cycle of the road, the energy requirements of the maintenance works might equal or outweigh the energy input required in road construction: $164.70 \mathrm{MJ} \mathrm{m}^{-1}$ for drainage system and $103.05 \mathrm{MJ} \mathrm{m}^{-1}$ for pavement works. Therefore, the total energy embodied in forest roads due to construction and maintenance would beabout $490.87 \mathrm{MJ} \mathrm{m}^{-1}$ in CSA 1 and $580.35 \mathrm{MJ} \mathrm{m}^{-1}$ in CSA 2. Considering the allowable cut of each CSA and the life cycle of the forest roads, this means an energy input per cubic meter of timber harvested of about 7.0 MJ in CSA 1 , respectively 7.3 MJ in CSA 2.

In what concerns the global warming potential of the forest road construction and maintenance, Table 11 shows the emission rates of $\mathrm{CO}_{2 \text { eq. }}$. per meter of road.

Forest road construction required about $16.6 \mathrm{~kg} \mathrm{CO}_{2 \mathrm{eq}} \mathrm{m}^{-1}$ in CSA 1 and about $23.0 \mathrm{~kg} \mathrm{CO}_{2 \mathrm{eq}} \mathrm{m}^{-1}$ in CSA 2 . In both cases, the embankment and pavement works accounted together for more than $90 \%$ of the total GHG emissions. Considering the AAC and the life cycle of the roads, this means road construction has an environmental footprint of $0.236 \mathrm{~kg} \mathrm{CO}_{2 \mathrm{eq}}$ in CSA 1, respectively of $0.251 \mathrm{~kg} \mathrm{CO}_{2 \mathrm{eq}}$ in CSA 2 per cubic meter of timber harvested. From the emissions point of view, road maintenance has a lower environmental footprint per one process as such, requiring $0.515 \mathrm{~kg} \mathrm{CO}_{2 \mathrm{eq}} \mathrm{m}^{-1}$ for maintaining drainage systems and $0.823 \mathrm{~kg} \mathrm{CO}_{2 \mathrm{eq}} \mathrm{m}^{-1}$ for maintaining the pavement structure. However, due to the repeated interventions during the road life cycle, the $\mathrm{CO}_{2 \mathrm{eq}}$ emission rates of road maintenance are comparable to those

Table 11 Emission rates of $\mathrm{CO}_{2 \text { eq }}$ from road construction and maintenance

\begin{tabular}{lllllll}
\hline \multicolumn{2}{l}{ GWP emissions of roads } & $\begin{array}{l}\text { Preparatory } \\
\text { works }\end{array}$ & $\begin{array}{l}\text { Embankment } \\
\text { works }\end{array}$ & $\begin{array}{l}\text { Drainage } \\
\text { system }\end{array}$ & $\begin{array}{l}\text { Pavement } \\
\text { works }\end{array}$ & Total \\
\hline $\mathrm{CO}_{2 \text { eq. }}$ & CSA 1 & 0.514 & 6.479 & 0.900 & 8.679 & 16.573 \\
$\left(\mathrm{~kg} \mathrm{~m}^{-1}\right)$ & & & & & & \\
& CSA 2 & 1.003 & 13.599 & 0.837 & 7.542 & 22.983 \\
& Maintenance & 0 & 0 & 12.345 & 7.725 & 20.070 \\
\hline
\end{tabular}




\section{A. Enache and K. Stampfer}

of the initial road construction, one meter of maintained road requiring about $20.1 \mathrm{~kg} \mathrm{CO}$ eq. In this study this means that in moderate slope conditions, the level of $\mathrm{CO}_{2 \mathrm{eq}}$ emissions from road maintenance works exceeds the emission levels from road construction in CSA 1 with about $21 \%$ and represent about $87 \%$ of the road construction requirements in difficult terrain conditions (CSA 2). Thus, road construction and maintenance works combined require about $36.6 \mathrm{~kg} \mathrm{CO}_{2 \mathrm{eq}} \mathrm{m}^{-1}$ in CSA 1 and $43.1 \mathrm{~kg} \mathrm{CO}_{2 \mathrm{eq}} \mathrm{m}^{-1}$ in CSA 2, respectively, which means emission rates of about $62.5 \mathrm{t} \mathrm{CO}_{2 \mathrm{eq}}$ in CSA 1 and $84.8 \mathrm{t} \mathrm{CO}_{2 \mathrm{eq}}$ in CSA 2 during the life cycle of the road. Considering the allowable cut in each case study area, these would mean about $0.521 \mathrm{~kg} \mathrm{CO}_{2 \mathrm{eq}}$ in CSA 1 and $0.471 \mathrm{~kg} \mathrm{CO}_{2 \text { eq }}$ in CSA 2 per cubic meter of timber harvested during the road life cycle.

The permanent surface occupied by the road bed was $10219 \mathrm{~m}^{2}$ in CSA 1 and $13108 \mathrm{~m}^{2}$ in CSA 2 (Table 12). The loss of productive land due to road construction was about $5.07 \mathrm{~m}^{2} \mathrm{y}^{-1}$ per cubic meter of wood in CSA 1 , respectively $5.82 \mathrm{~m}^{2} \mathrm{y}^{-1}$ in CSA 2. Considering the mean annual growth of forests in the study area $\left(6 \mathrm{~m}^{3} \mathrm{ha}^{-1} \mathrm{y}^{-1}\right)$ and that one cubic meter of wood binds about 1.1 tones $\mathrm{CO}_{2 \mathrm{eq}}$ from the atmosphere (Hasenauer, 2014), this means about $6.74 \mathrm{t} \mathrm{CO}_{2 \text { eq }}$ in CSA 1 and $8.65 \mathrm{t} \mathrm{CO}_{2 \mathrm{eq}}$ in CSA 2 are not bound each year due to the loss of productive forest land. Reporting these figures to the road unit, it means that occupying productive forest land with forest roads requires $3.95 \mathrm{~kg} \mathrm{CO}_{2 \mathrm{eq}} \mathrm{m}^{-1} \mathrm{y}^{-1}$ in CSA 1 and $4.40 \mathrm{~kg} \mathrm{CO}_{2 \mathrm{eq}} \mathrm{m}^{-1} \mathrm{y}^{-1}$ in CSA 2.

The $\mathrm{CO}_{2 \text { eq }}$ emissions due to loss of productive land can be only partially compensated by the $\mathrm{CO}_{2 \text { eq }}$ stored in the timber harvested from the road bed clearance (Table 12). For clearing the road bed, about $407 \mathrm{~m}^{3}$ were harvested in CSA 1 and $297 \mathrm{~m}^{3}$ in CSA 2, which is equivalent to $447.7 \mathrm{CO}_{2 \mathrm{eq}}$ and $326.7 \mathrm{t} \mathrm{CO}_{2 \text { eq }}$, respectively. Considering that approximately $40 \%$ of the harvested timber is used for wood products and $60 \%$ as energy wood by

Table 12 Impact of road bed clearance on $\mathrm{CO}_{2 \mathrm{eq}}$ emissions

\begin{tabular}{llrc}
\hline Index & Item & CSA 1 & CSA 2 \\
\hline 1 & Cleared road bed surface (ha) & 1.02 & 1.31 \\
2 & $\mathrm{CO}_{2 \text { eq }}$ emissions due to loss of productive land $\left(\mathrm{t} \mathrm{CO}_{2 \mathrm{eq}}\right)$ & 202.2 & 259.5 \\
3 & $\mathrm{CO}_{2 \text { eq }}$ from timber harvest road bed $(\mathrm{t})$, of which: & 447.7 & 326.7 \\
4 & - stored in wood products $\left(\mathrm{t} \mathrm{CO}_{2 \mathrm{eq}}\right)$ & 179.1 & 130.7 \\
5 & - emissions to atmosphere $\left(\mathrm{t} \mathrm{CO}_{2 \mathrm{eq}}\right)$ & 268.6 & 196.0 \\
6 & $\mathrm{CO}_{2 \mathrm{eq}}$ balance of the road bed clearance $\left(\mathrm{t} \mathrm{CO}_{2 \mathrm{eq}}\right)$ & & \\
& {$[(6)=(4)-(5)-(2)]$} & -291.7 & -324.8 \\
\hline
\end{tabular}


Table 13 Impact of lost productive land on $\mathrm{CO}_{2 \text { eq }}$ emissions during road life cycle

\begin{tabular}{|c|c|c|c|}
\hline Index & Item & CSA 1 & CSA 2 \\
\hline 1 & Total $\mathrm{CO}_{2 \mathrm{eq}}$ of current standing volume $\left(\mathrm{t} \mathrm{CO}_{2 \mathrm{eq}}\right)$ & 316530 & 282750 \\
\hline 2 & $\begin{array}{l}\text { Total } \mathrm{CO}_{2 \mathrm{eq}} \text { of timber harvested in } 30 \text { years }\left(\mathrm{t} \mathrm{CO}_{2 \mathrm{eq}}\right) \text {, } \\
\text { of which: }\end{array}$ & 132000 & $124960-$ \\
\hline 3 & - stored in timber products $\left(\mathrm{t} \mathrm{CO}_{2 \mathrm{eq}}\right)$ & 52800 & $50000-$ \\
\hline 4 & - emissions in atmosphere by energy wood $\left(\mathrm{t} \mathrm{CO}_{2 \mathrm{eq}}\right)$ & 79200 & $84960-$ \\
\hline 5 & $\mathrm{CO}_{2 \mathrm{eq}}$ of net standing volume in 30 years $\left(\mathrm{t} \mathrm{CO}_{2 \mathrm{eq}}\right)$ & 351040 & $308520-$ \\
\hline 6 & $\mathrm{CO}_{2 \mathrm{eq}}$ balance of the road bed clearance $\left(\mathrm{t} \mathrm{CO}_{2 \mathrm{eq}}\right)$ & -291.7 & -324.8 \\
\hline 7 & $\begin{array}{l}\mathrm{CO}_{2 \text { eq }} \text { balance of road construction and } \\
\text { maintenance }\left(\mathrm{t} \mathrm{CO}_{2 \mathrm{eq}}\right)\end{array}$ & -62.4 & -84.8 \\
\hline 8 & $\begin{array}{l}\mathrm{CO}_{2 \mathrm{eq}} \text { balance of the opened forest area }\left(\mathrm{t} \mathrm{CO}_{2 \mathrm{eq}}\right) \\
{[(8)=(7)+(6)+(5)+(3)-(4)]}\end{array}$ & 324285 & 273150 \\
\hline
\end{tabular}

the forest enterprise, this means during the life cycle of the forest roads approximately $130.7 \mathrm{t} \mathrm{CO}_{2 \text { eq }}$ in CSA 2 and $179.1 \mathrm{t} \mathrm{CO}_{2 \text { eq }}$ in CSA 1 can be stored in wood products, the rest being released back in the atmosphere through the burning process. Table 12 reveals that occupying productive forest land with roads means a net loss of $291.7 \mathrm{t} \mathrm{CO}_{2 \mathrm{eq}}$ in $\mathrm{CSA} 1$ and $324.8 \mathrm{t} \mathrm{CO}_{2 \mathrm{eq}}$ in CSA 2.

Notwithstanding, the net $\mathrm{CO}_{2 \mathrm{eq}}$ emissions due to loss of productive land are insignificant when compared to the amount of $\mathrm{CO}_{2 \mathrm{eq}}$ stored in the growing stock of the opened forest area. Table 13 shows the balance of $\mathrm{CO}_{2 \mathrm{eq}}$ due to the loss of productive land occupied by the roads during their entire life cycle for the forest area opened by the road construction in both CSAs. The $\mathrm{CO}_{2 \mathrm{eq}}$ balance was calculated as an algebraic sum of the $\mathrm{CO}_{2}$ eq gains (i.e. current standing volume, increment during the life cycle of the road, storage in wood products) and $\mathrm{CO}_{2 \mathrm{eq}}$ losses (i.e. emissions in atmosphere by combustion of energy wood). The $\mathrm{CO}_{2 \text { eq }}$ emissions due to machinery utilization in timber harvesting were not included in this analysis.

\section{Discussions and Conclusions}

Forest road construction is an intensive process in what concerns machinery utilization, labor required, energy input and GHG emissions. The most energy intensive processes in road construction reported in this study were the embankment and the pavement works, accounting for about $90 \%$ of the total energy requirements in each CSA. The most intensive energy consumers and $\mathrm{CO}_{2}$ emissions generators were the excavator, the dump truck and the front 


\section{A. Enache and K. Stampfer}

loader, accounting for about $70 \%$ of the total necessary machine utilization hours in each case study area.

On the other hand, road maintenance works are also energy intensive. Although one event of road maintenance is not so energy demanding (about $17.85 \mathrm{MJ} \mathrm{m}^{-1}$ ) compared to road construction, the total energy required for maintenance works during the life cycle of the road $\left(267.75 \mathrm{MJ} \mathrm{m}^{-1}\right)$ outweighs with about $20 \%$ the energy requirements for road construction in CSA 1 and represents about 85\% of these in CSA 2. Basically, this means that maintaining valley forest roads over a life cycle of 30 years is almost as much energy intensive as the road construction, especially because of the number of repeated interventions. This is due to the wellknown fact that valley forest roads are susceptible to more damages than slope roads, due to their vicinity to the water courses, particularly during spring and heavy precipitation season (i.e. snow melting and torrential flows). Therefore, it would be better from the point of view of energy input and GHG emissions to reduce the number of maintenance operations. This could be the case of road networks with more slope roads rather than with valley roads.

The total energy embodied in forest roads (construction and maintenance) was $490.87 \mathrm{MJ} \mathrm{m}^{-1}$ in CSA 1 and $580.35 \mathrm{MJ} \mathrm{m}^{-1}$ in CSA 2, respectively. In comparison, Heinimann (2012) estimated energy input rates for road construction and maintenance between 315 and $735 \mathrm{MJ} \mathrm{m}^{-1}$ road, depending on the side slope variation, while Whittaker et al. (2011) reported energy

requirements of $403 \mathrm{MJ} \mathrm{m}^{-1}$ for road construction and $102 \mathrm{MJ} \mathrm{m}^{-1}$ for road maintenance, including the requirements of machine manufacture and maintenance. However, all these figures should be cautiously interpreted, looking at the characteristics of each study layout (i.e. topographical conditions, definition of the system borders).

One particularly important observation is that in this study the amount of fuel consumed in road construction (6.19 liters $\mathrm{m}^{-1}$ in CSA 1 and 8.58 liters $\mathrm{m}^{-1}$ in CSA 2) was almost similar to the amount of fuel needed forroad maintenance $\left(7.5\right.$ liters $\mathrm{m}^{-1}$ ) during the life cycle of the forest road. Thus, it can be underlined that the quality of the planning process and of the construction of forest roads plays a crucial role in the future running costs of a road network. Slope forest roads are easier and less costly to maintain than valley roads. Loeffler et al. (2009) estimated fuel consumption rates for road construction in full bench profile varying between 7.7 liters and 18.9 liters per meter of road depending on the side slopes (between $50 \%$ and 90\%), while Whittaker et al. (2011) reported about 4.7 liters of fuel for building 
one meter of road, in a case study from Scotland. The terrain conditions and the characteristics of the forest road built in CSA 2 of this study were closer to those assumed by Loeffler et al. (2009) and so were the results regarding the fuel consumption.

The outcomes of this study have showed that road construction and maintenance operations are important sources of GHG emissions. The management practices (i.e. slope roads versus valley roads, share of timber used for timber products versus bio-energy) might have an influence on the environmental footprint of forest roads. However, the quantity of $\mathrm{CO}_{2 \mathrm{eq}}$ emissions from clearing the road bed, building and maintaining the road is insignificant in the equation of the $\mathrm{CO}_{2 \mathrm{eq}}$ emissions balance over the road life cycle. Hence, increasing the density of forest roads with about $2.0 \mathrm{~m} \mathrm{ha}^{-1}$ in each case study area is worth while from the point of view of GHG emissions balance. Comparable findings were reported in the literature. Loeffler et al. (2009) estimated $\mathrm{CO}_{2}$ emissions from road construction between $20.9 \mathrm{~kg} \mathrm{~m}^{-1}$ and $51.5 \mathrm{~kg} \mathrm{~m}^{-1}$ depending on the side slope variation, while Whittaker et al. (2011) showed about $37.8 \mathrm{~kg} \mathrm{CO}_{2}$ were required for building and maintaining one meter of road. Heinimann (2012) reported $\mathrm{CO}_{2}$ output rates of road construction and maintenance between $19 \mathrm{~kg} \mathrm{~m}^{-1}$ to $47 \mathrm{~kg} \mathrm{~m}^{-1}$ depending on the terrain side slope conditions. Terrain characteristics have showed a strong influence on the amount of fuel consumption, the required energy inputs and the GHG emissions in this study, too. It was showed that steeper slopes and stonier terrain finally lead to higher environmental burden (i.e. $43.1 \mathrm{~kg} \mathrm{CO}_{2 \mathrm{eq}} \mathrm{m}^{-1}$ in CSA 2 compared to $36.6 \mathrm{~kg} \mathrm{CO}_{2 \mathrm{eq}} \mathrm{m}^{-1}$ in CSA 1) and higher road construction costs (i.e. $120 € \mathrm{~m}^{-1}$ in CSA 2 compared to $88 € \mathrm{~m}^{-1}$ in CSA 1). However, road construction costs are still very high when compared to similar terrain conditions from other countries. For example, in Austria, the road construction costs may vary from $14 € \mathrm{~m}^{-1}$ and100 $€ \mathrm{~m}^{-1}$ depending on the terrain slope and stoniness, while the average cost is about $35 € \mathrm{~m}^{-1}$ (Ghaffariyan et al. 2010).

The input-output LCA approach proved to be a useful tool for assessing the energy requirements and GHG emission levels of forest roads. Though, setting the system boundaries and the time scale, gathering and analyzing data represent challenging and time consuming tasks. A natural further step of this study would be the accounting of the energy and emissions of different harvesting systems in mountain regions with and without forest roads, in order to see the impact of forest infrastructure development on the environmental footprint of harvesting operations. 


\section{Acknowledgments}

The authors would like to thank Hendrik Schubert and Constantin Vasilică from Lignum Forest Enterprise for their support in data collection and feedback during data analysis. We would also like to thank the two anonymous reviewers for their valuable comments and suggestions.

\section{References}

[1] Abrudan, I. V., Marinescu, V., Ionescu, O., Ioras, F., Horodnic, S. A., and Sestras, R. 2009. Developments in the Romanian forestry and its linkages with other sectors. Notulae Botanicae Horti Agrobotanici Cluj-Napoca 37(2):14-21.

[2] Borz, S. A., Dinulica, F., Birda, M., Ignea, G., Ciobanu, V. D., Popa, B. 2013. Time consumption and productivity of skidding silver fir (Abies alba Mill.) round wood in reduced accessibility conditions: a case study in windthrow salvage logging from Romanian Carpathians. Annals of Forest Research 56(2):363-375.

[3] Bosner, A., Poršinsky, T., and Stankić, I. 2012. Forestry and life cycle assessment. P. 139-160 in Global perspectives on sustainable forest management, Dr. Clement A. Okia (Ed.). InTech, ISBN: 978-953-510569-5.

[4] Berg, S. and Karjalainen, T. 2003. Comparison of greenhouse gas emissions from forest operations in Finland and Sweden. Forestry 76(3):271-284.

[5] Berg, S. and Lindholm, E.-L. 2005. Energy use and environmental impacts of forest operations in Sweden. Journal of Cleaner Production 13:33-42.

[6] Coulter, E. D. 2004. Setting forest road maintenance and upgrade priorities based on environmental effects and expert judgment. $\mathrm{PhD}$ Thesis, Oregon State University, Corvallis, 199 p.

[7] Enache, A., Kühmaier, M., Stampfer, K., Ciobanu, V. D. 2013. An integrative decision support tool for assessing forest roads options in a mountainous region in Romania. Croatian Journal of Forest Engineering 34 (1):43-60.

[8] Ghaffariyan, M. R., Stampfer, K., Sessions, J., Durston, T., Kuehmaier, M., Kanzian, C. (2010): Road network optimization heuristic and linear programming. Journal of Forest Science 56(3): 137-145. 
[9] Heinimann, H. R. and Maeda-Inaba, S. 2003. Quantification of environmental performance indicators EPIS for forest roads. In: Proceedings of Austro 2003: High Tech Forest Operations for Mountainous Terrain, Schlaegl, Austria, 13 p.

[10] Heinimann, H. R. 2012. Life cycle assessment (LCA) in Forestry State and Perspectives. Croatian Journal of Forest Engineering 33(2): 357-372.

[11] Holzleitner, F., Kanzian, C., and Stampfer, K. 2011. Analyzing time and fuel consumption in road transport of round wood with an onboard fleet manager. European Journal of Forest Research 130:293-301.

[12] Johnson, L. R., Lippke, B., Marshall, J. D., and Comnick, J. 2005. Lifecycle impacts of forest resource activities in the Pacific Northwest and Southeast United States. Wood and Fiber Sciences 37:30-46.

[13] Karjalainen, T., Pussinen, A., Liski, J., Nabuurs, G.-J., Eggers, T., Lapvetelainen, T., and Kaipainen, T. 2003. Scenario analysis of the impacts of forest management and climate change on the European forest sector carbon budget. Forest Policy and Economics 5: 141-155.

[14] Klvac, R., Fischer, R., and Skoupy, A. 2012. Energy use of and emissions from the operation phase of a medium distance cableway system. Croatian Journal of Forest Engineering 33(1):79-88.

[15] Loeffler, D., Jones, G., Vonessen, N., Healey, S., and Chung, W. 2008. Estimating diesel fuel consumption and carbon dioxide emissions from forest road construction. In: Proc. Forest Inventory and Analysis (FIA) Symposium 2008 RMRS-P-56CD, McWilliams et al. (Ed.), Fort Collins, $11 \mathrm{p}$.

[16] Meister, G. (1995): Eco-balances in the pulp industry: assessment of environmental impacts. P. 107-114 In: Proc. of the International Workshop "Life cycle analysis - a challenge for forestry and forest industry", Hamburg, Germany.

[17] Michelsen, O., Solli, C., and Stromman, A. H. 2008. Environmental impact and added value in forestry operations in Norway. Journal of Industrial Ecology 12 (1): 69-81.

[18] Mills, K. (2006): Environmental performance measures for forest roads. P. 291-300 In: Proc. of the $29^{\text {th }}$ Council on Forest Engineering Conference: "Working globally - sharing forest engineering challenges and technologies around the world", Coeur d'Alene, Idaho. 
[19] Olofsson, P., Kuemmerle, T., Griffiths, P., Knorn, J., Baccini, A., Gancz, V., Blujdea, V., Houghton, R. A., Abrudan, I. V., and Woodcock, C. E. 2011. Carbon implications of forest restitution in post-socialist Romania. Environmental Research Letters 6: 045202, 10 p.

[20] Olteanu, N. 2009. Considerations regarding the optimum density in Romanian forests. P. 701-708 In: Proc. of the Biennial International Symposium "Forest and Sustainable Development 2008", Transilvania University of Brasov.

[21] Popovici, V., Bereziuc, R., and Clinciu, I. 2006. Considerations regarding the enhancement of the forest road network for opening up the forests. Revista Padurilor 121(6):19-21.

[22] Richter, K. (1995): Life cycle analysis of wood products. P. 69-77 In: Proc. of the International Workshop "Life cycle analysis - a challenge for forestry and forest industry”, Hamburg, Germany.

[23] Seppala, J., Melanen, M., Jouttijarvi, T., Kauppi, L., and Leikola, N. 1998. Forest industry and the environment: a life cycle assessment study from Finland. Resources, Conservation and Recycling 23: 87-105.

[24] Sharrard, A. L. 2007. Greening Construction Processes Using an Input-Output-Based Hybrid Life Cycle Assessment Model. PhD thesis, Carnegie Mellon University Pittsburgh, Pennsylvania, 343 p.

[25] Stanescu, R. C. 2012. Research concerning production technologies and properties of biofuels for vehicles. PhD Dissertation, Transilvania University of Brasov, Romania.

[26] Treloar, G. J., Love, P. E. D., and Crawford, R. H. 2004. Hybrid life-cycle inventory for road construction and use. Jour. of Constr. Eng. and Manag. 130(1):43-49.

[27] Whittaker, C., Mortimer, N., Murphy, R., and Matthews, R. 2011. Energy and greenhouse gas balance of the use of forest residues for bioenergy production in UK. Biomass and Bioenergy 35: 4581-4594.

[28] World Bank 2012. Functional Analysis of the Sector Environment and Forests in Romania - Vol. 1 \& 2. - Final Report, 66 p. 


\section{Biographies}

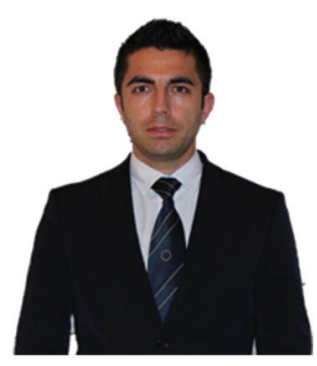

Adrian Enache is a research associate at the Institute of Forest Engineering from the University of Natural Resources and Life Sciences (BOKU) -Vienna, Austria. His work focuses on efficiency gaps analysis and multiple criteria decision making in timber harvesting and road network planning in mountain forests (ARANGE project). He holds a doctor degree in forestry (Transilvania University of Brasov-UNITBV, Romania, 2013), a master degree in mountain forestry (BOKU, 2009), a certification in project management (CODECS, 2007) and a diploma engineer degree in forestry (UNITBV, 2005). Since 2011 he is enrolled in a PhD program at BOKU.

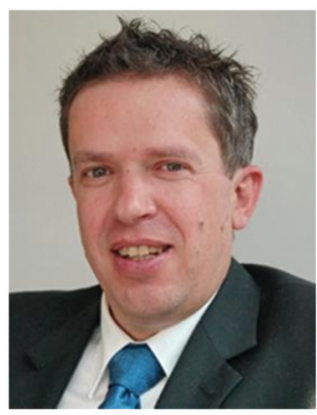

Karl Stampfer is professor at the Institute of Forest Engineering at BOKU, Vienna. His expertize is related to the multi-dimensional aspects of the wood supply chain (i.e. timber harvesting, road network planning, logistics, cable yarding, ergonomics). He holds a doctoral degree in forestry since 1996 (BOKU) and his habilitation was in 2002 (BOKU). He received several international awards and he is member in numerous international professional societies (i.e. IUFRO, Austrian Association for Agricultural Research, Croatian Academy of Forestry Sciences). Since 2003 he is the chairman of FORMEC - International Symposium on Forestry Mechanization. 
